\title{
Why do firms bribe? An empirical study in BRICS economies from 2002 to 2012
}

\author{
Ruohan Wu* \\ Department of Accounting and Finance, College of Business Administration, Alabama State University, USA
}

Received: 18 March 2016

Revised: 15 September 2016

Accepted: 2 October 2016

\begin{abstract}
This article empirically studies why manufacturing firms bribe the government officials. Firmlevel data focusing on the five BRICS countries (Brazil, Russia, India, China, and South Africa) was acquired from an Enterprise Survey conducted by the World Bank between 2002 and 2012. The BRICS countries represent typical emerging world economies. We acquired country-level data from multiple sources. We then studied both firm-level and country-level reasons why firms bribe and how much money they spend in bribing. We found that smaller size, slower expansion, and more infrastructural defects significantly increase bribery probability. Bribery also tends to occur more frequently in countries with faster development and more political rigidity. The 2007-2009 financial crisis also encouraged bribery.
\end{abstract}

Keywords: BRICS; corruption; bribe; firm; country.

JEL Classification Codes: D22, D73, O17

\section{Introduction}

Why do firms bribe? This is a sensitive yet intriguing question. A firm may resort to unaudited and unreported payment to government officials in order to survive competition, gain more resources, secure necessary operations contracts, or even to cope with threats from authorities. As a result, violations of rules or qualifications standards will be intentionally ignored, and the government will intentionally offer firms some convenience apart from the efficient allocation of the market. Firms can benefit from bribery, but what types of firms are more likely to bribe? What are the possible causes?

For this study, we selected several typical firm-level factors. First, we considered employment size and growth (Svensson, 2003; Clarke and Xu, 2004; Wu, 2009). Whether large or small firms tend to bribe more is a point of controversy. According to the "endogenous

\footnotetext{
*E-mail: rwu@alasu.edu.

Citation: Wu, R. (2016) Why do firms bribe? An empirical study in BRICS economies from 2002 to 2012, Economics and Business Letters, 5(3), 72-79.
} 
harassment" model by Myrdal (1968), predatory officials demand bribes from targeted firms based on their "ability to pay." But our results show otherwise: Firms with small sizes and slower growth tend to bribe more often. Next, we considered defective infrastructure. The more a firm encounters or has to cope with resource shortage and crimes, the more likely it is to bribe.

Additionally, we focused on country-level factors. Across-country analysis has been conducted by many existing literatures (Chen et al., 2008; Martin et al., 2007; Sanyal, 2005). Powpaka (2002) used data from Thailand and discussed managers' perspectives and decisions upon bribery. Cheung et al. (2012) found that police forces, civil liberties, and bureaucratic rigidities significantly affect firms' bribing activities. Influence of cultural and institutional factors is also confirmed by Martin et al. (2007). Our article focuses on the aggregate economic environment. Bribery is more likely to occur in a fast-growing, corrupt, and politically rigid country. We also found that the 2007-2009 financial crisis encouraged more bribery.

We focused on the BRICS countries: Brazil, Russia, India, China, and South Africa. These five countries represent highly industrialized developing countries, as the new emerging economies of highly industrialized developing countries. They are also known as leaders of the new developing world. According to the World Bank national accounts data, these five nations have a combined nominal gross domestic product (GDP) of more than $\$ 16.9$ trillion, or approximately $21.8 \%$ of the gross world product. According to statistics from the United Nations Population Division, they represent $42 \%$ of the world population by hosting more than 3 billion people. The annual BRICS forum has attracted global attention since its formation in 2011 because of its great boost of global commercial and political cooperation.

Despite their fast economic development, corruption in the BRICS countries is considered severe. A corruption perception index (CPI) is compiled annually by Transparency International, a non-governmental organization that ranks countries and territories based on how corrupt their public sector is perceived to be. The index is scored from 0 to 100; the higher the index score, the less corrupt the country. In 2012 the CPI of Russia, India, and China are 28, 36, and 39, respectively, while the CPI of both South Africa and Brazil is 43. Figure 1 compares the average CPI scores of BRICS countries and five global economic and political organizations: the Group of Seven (G7), Organization of the Petroleum Exporting Countries (OPEC), European Union (EU), North American Free Trade Agreement (NAFTA), and the Group of Twenty (G20). The BRICS countries still have the lowest CPI-in other words, the most serious corruption. Therefore, it is important to study the corruption issues in BRICS.

Figure 1. Comparison of Average CPI among BRICS and other Global Organizations, 2012.

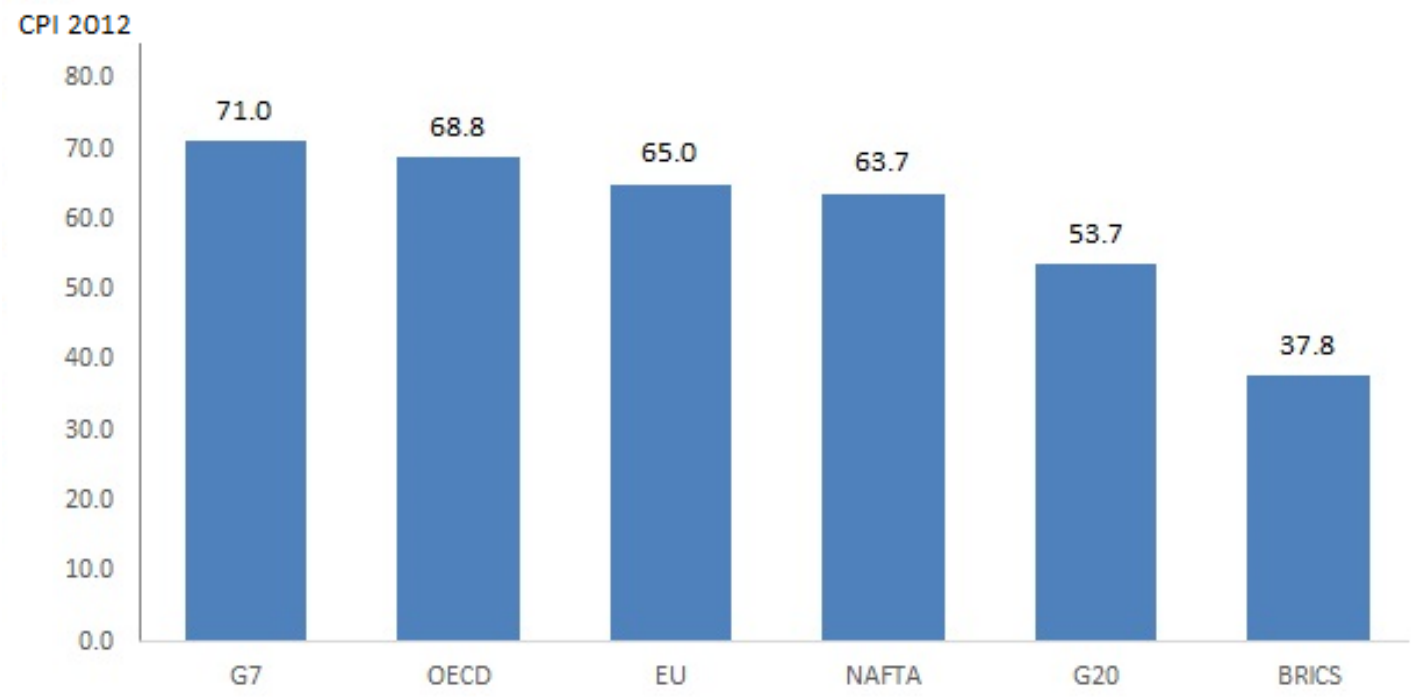

Source: Transparency International, http://www.transparency.org/research/cpi/overview. 
This paper is organized as follows. Section I provides introduction. Section II presents test methodology. Section III describes the data we acquire and use for analysis. Section IV explains the results, while Section IV concludes.

\section{Methods}

We developed a nonstructural estimation for the firms' bribing status:

$$
\text { Bribe }_{i t}=\left\{\begin{array}{l}
1, \text { if } \alpha Y_{i t-1}+\beta X_{i t-1}+\theta_{i}+\xi_{i t} \geq 0 \\
0, \text { otherwise }
\end{array}\right.
$$

Bribe $_{\text {it }}$ is a binary-status variable of whether the firm pays for bribe. It equals 1 if the firm bribes, and 0 otherwise. $\alpha$ includes the coefficients of all firm-level characteristics captured in $Y_{\mathrm{it}} . \beta$ includes the coefficients of all country-level characteristics in $X_{\mathrm{it}} . Y$ and $X$ are lagged by 1 period to avoid potential endogeneity. To be specific, we split the error term into two parts: a firm-specific effect $\theta_{\mathrm{i}}$, which is time-invariant, such as country fixed effect, and an unobserved white noise $\xi_{\text {it. }}$ We used probit estimation due to the binary-status characteristics of the firms' decisions.

Furthermore, to study how the firm-level and country-level characteristics affect bribing firms' decisions of how much to pay, we also used the linear estimation:

$$
\text { Bribe } \%_{i t}=\alpha Y_{i t-1}+\beta X_{i t-1}+\theta_{i}+\xi_{i t}
$$

Bribe $\%_{\text {it }}$ is the amount of firms' bribes as a percentage of their annual sales. To keep our analysis simple and intuitive, we used ordinary least squares method. Notice that this estimation is only conducted among those bribing firms $\left(\right.$ Bribe $\left._{\text {it }}=1\right)$ to examine their bribery expenditure amount. In the following analysis, we will focus on these coefficient vectors ( $\alpha$ and $\beta$ ) and examine their significance and economic intuition.

\section{Data}

We acquired data from an Enterprise Survey conducted by the World Bank from 2002 to 2012. The survey collected information from firms all over the world. It includes information about locations, ages, sectors, annual sales, employment, expenditures, etc. More importantly, it includes firms' underground activities, including bribery. In this article, we focus only on data from BRICS countries to conduct our analysis.

Notice that we only select those firms who clearly responded "yes" or "no" when they are asked whether they had bribed the government officials previously. Firms who did not answer the question are excluded from our consideration. Among all the 13,810 observations we sampled from BRICS countries, 7,473 (54\%) come from India, 2,430 (18\%) from Russia and 2,161 (15\%) from China. Only $960(7 \%)$ of the firms are located in Brazil, and $786(6 \%)$ in South Africa. The distribution details of bribing and non-bribing firms across these five countries are depicted in Figure 2 and 3.

The vertical axis in Figure 2 counts the number of the firms paying and not paying for briberies, while that in Figure 3 counts the percentage of each types of firms in every country. Generally speaking, most firms did not pay bribery. Among all the observed firms, 1,602 $(11.6 \%)$ reported that they did pay briberies such as informal and unaudited gifts to government officers, in order to "get things done" with regard to customs, taxes, licenses, regulations, services, etc. However, big variation exists. Nearly $19 \%$ of the observed firms in Russia while less than $5 \%$ of Chinese firms bribed.

To study determinants of bribery, we focused on firm-level and country-level analysis: first, a firm's scale (employment and market experience); second, infrastructural defects (cost of 
resource shortage, loss due to crimes and insecurity, and how much the firm pays out of its annual sales on security); third, an external audit dummy that equals 1 if a firm annually goes through an external financial audit, or 0 otherwise.

Figure 2. Distribution of Bribing and Non-Bribing Firms across BRICS (Number)

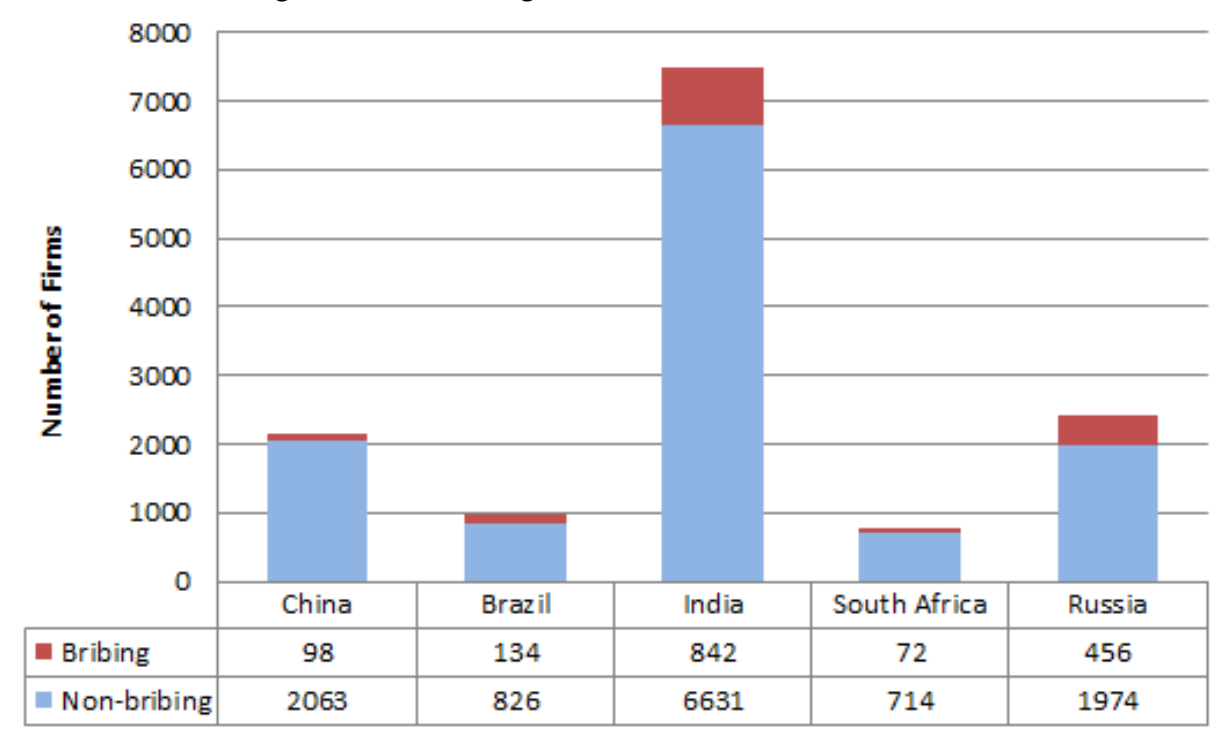

Source: Enterprise Survey, World Bank 2002 - 2012.

Figure 3. Distribution of Bribing and Non-Bribing Firms across BRICS (Percentage)

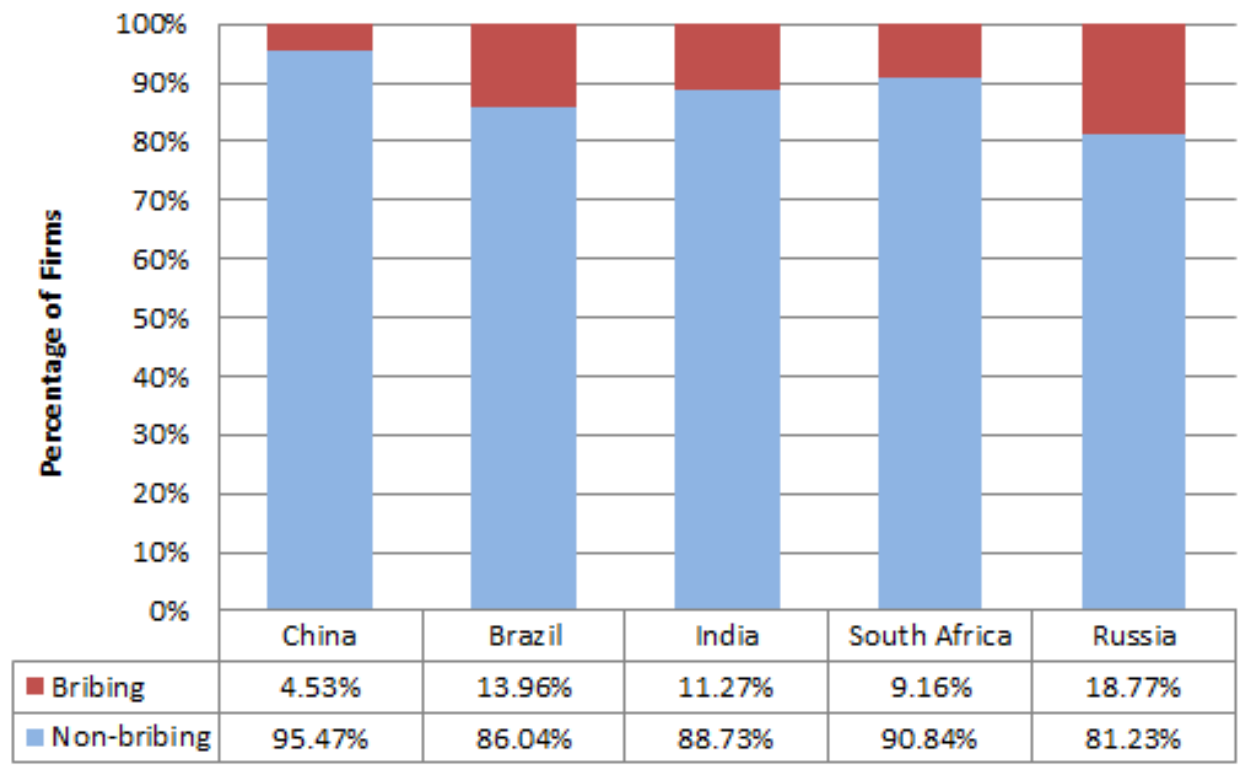

Source: Enterprise Survey, World Bank 2002 - 2012.

Regarding country-level analysis, we were interested in corruption, the political environment, and the country's development level. We use the CPI discussed above to interpret corruption. To measure national development level, we used annual GDP growth rate extracted from Penn World Table 8.0. We also adopted the Political Constraint Index developed by Henisz (2002), which has been used extensively in business research, including firms' bribery decisions (Martin et al., 2007). It measures the veto power from independent branches of government against the chief executives, either individuals or collectives, as well as the different political preferences across these branches. Henisz's dataset also includes an index of 
law and order tradition. This index measures the degree to which a country's citizens are willing to accept the lawmakers' policymaking power. The higher the indicator is, the more willingness the citizens have, and the stronger the law and order tradition is.

Comparing across the BRICS countries, Table 1 describes the averages of four country-level variables that we include in our estimation: corruption perception index (CPI), political constraint index, law and order tradition index, and annual GDP growth rate. Within all these five countries, China features the fastest growth between 2002 and 2012, the most rigid political system, and the strongest willingness of its citizens to accept the authorities to make laws. South Africa has the lowest growth rate but the highest CPI, which represents the least severe corruption issue. Russia, meanwhile, is the most corrupt.

Table 1. Comparison between Country-Level Variables across BRICS.

\begin{tabular}{|c|c|c|c|c|}
\hline \multirow[b]{2}{*}{ Country } & \multicolumn{4}{|c|}{ Average between 2002 and 2012} \\
\hline & $\begin{array}{c}\text { Corruption } \\
\text { Perception Index }\end{array}$ & $\begin{array}{c}\text { Political Constraint } \\
\text { Index }{ }^{b}\end{array}$ & $\begin{array}{l}\text { Law and Order } \\
\text { Tradition Index }\end{array}$ & $\begin{array}{l}\text { GDP Growth } \\
\text { Rate }(\%)^{c}\end{array}$ \\
\hline China & 35.46 & 0.00 & 4.21 & 10.38 \\
\hline Brazil & 38.31 & 0.26 & 1.75 & 3.74 \\
\hline India & 32.46 & 0.42 & 4.00 & 7.48 \\
\hline South Africa & 45.46 & 0.44 & 2.00 & 3.41 \\
\hline Russia & 25.00 & 0.33 & 3.86 & 4.72 \\
\hline
\end{tabular}

Source: ${ }^{\mathrm{a}}$ Transparency International; ${ }^{\mathrm{b}}$ Political Constraint Index Dataset 2012; ${ }^{\mathrm{c}}$ Penn World Table 8.0.

\section{Results}

The test results are shown in Table 2. Columns (i) and (ii) are based on Eq. 1, while columns (iii) and (iv) are from Eq. 2. We will start from the binary analysis, which treats bribery as a discrete status. The findings are highly consistent. Firms with fewer employees and those that experience less growth tend to bribe more. Meanwhile, infrastructural defects have significantly positive effects. Firms that face higher risks of theft, and that consequently pay more for security equipment and personnel, tend to bribe, as do those firms experiencing severe resource shortage. Going through external financial audits significantly decreases the probability of bribing.

Unsurprisingly, firms in countries with lower CPI, or with more corruption, tend to bribe. Less political constraint and longer legitimate tradition also decrease the potential for bribery. Interestingly, faster growing GDP results in more briberies; this growth paradox clearly contradicts the traditional studies (Keefer and Knack, 1997; Campos et al., 1999; Kaufmann and Wei, 1999; Méon and Sekkat, 2005) which argues corruption hinders a country's development. The turmoil during the 2007-2009 global financial crisis increased the probability that firms will bribe. Under the estimation with country dummies, it is found that bribery is most likely to happen in Russia and least likely to happen in Brazil.

Next, we examined the linear analysis that includes bribery as a percentage of the firm's annual sales. Unlike the binary analysis above, here we only studied those firms that did pay bribes. The determinants of how much to bribe are similar to, yet different from, the factors that determine whether to bribe. In this case, the size of the firm does not factor into the decision of how much to pay for bribery. However, among those firms that bribe, older firms spend more on bribery, despite the previous finding that more young firms bribe. Still, infrastructural factors matter. Crime losses, security payments, and resource shortages all significantly increase the amount a firm pays in bribes. A firm that goes through financial review by an external auditor is likely to pay significantly less. The stronger the tradition for the country's citizens to accept the national law and order system is, the less a firm would bribe. 
Table 2. Determinants of Bribery, BRICS Countries 2002-2012.

\begin{tabular}{|c|c|c|c|c|}
\hline & \multicolumn{2}{|c|}{$\begin{array}{c}\text { Bribery Decision } \\
\left(\text { Bribe }_{i t}\right)\end{array}$} & \multicolumn{2}{|c|}{$\begin{array}{c}\text { Bribery Percentage } \\
\left(\text { Bribe } \%_{i t}\right)\end{array}$} \\
\hline & (i) & (ii) & (iii) & (iv) \\
\hline \multicolumn{5}{|l|}{ Firm-Level } \\
\hline Employees & $\begin{array}{c}-0.139 * * * \\
(0.045)\end{array}$ & $\begin{array}{c}-0.137 * * * \\
(0.045)\end{array}$ & $\begin{array}{l}-0.514 \\
(0.550)\end{array}$ & $\begin{array}{l}-0.514 \\
(0.550)\end{array}$ \\
\hline Years of Growth & $\begin{array}{l}-0.273 * \\
(0.153)\end{array}$ & $\begin{array}{l}-0.277 \\
0.160)\end{array}$ & $\begin{array}{c}0.112 \\
(2.532)\end{array}$ & $\begin{array}{c}0.111 \\
(2.532)\end{array}$ \\
\hline $\begin{array}{c}\text { Sales Growth Rate since } \\
3 \text { years ago }\end{array}$ & $\begin{array}{l}-0.520 * * \\
(0.226)\end{array}$ & $\begin{array}{c}-0.507 * * \\
(0.227)\end{array}$ & $\begin{array}{l}-0.423 \\
(0.277)\end{array}$ & $\begin{array}{l}-0.423 \\
(0.277)\end{array}$ \\
\hline Security Payment as \% & $2.847 * * *$ & $3.090 * * *$ & $13.59 * * *$ & $13.59 * * *$ \\
\hline Annual Sales & $(0.312)$ & $(0.318)$ & $(2.607)$ & $(2.607)$ \\
\hline Loss \% Due to Thefts & $0.774 *$ & $0.821^{*}$ & $1.682 * * *$ & $1.682 * *$ \\
\hline and other Crimes & $(0.459)$ & $(0.459)$ & $(0.645)$ & $(0.645)$ \\
\hline Loss \% Due to & $1.012 * * *$ & $0.868 * * *$ & $5.198^{*}$ & $5.198^{*}$ \\
\hline Resource Shortage & $(0.254)$ & $(0.257)$ & $(2.713)$ & (2.713) \\
\hline External Audit Dummy & $\begin{array}{c}-0.155 * * * \\
(0.036)\end{array}$ & $\begin{array}{c}-0.170 * * * \\
(0.036)\end{array}$ & $\begin{array}{l}-0.762 * \\
(0.452)\end{array}$ & $\begin{array}{l}-0.762 * \\
(0.452)\end{array}$ \\
\hline \multicolumn{5}{|l|}{ Country-Level } \\
\hline $\begin{array}{l}\text { Corruption Perception } \\
\text { Index (CPI) }\end{array}$ & $\begin{array}{c}-0.126^{* * * *} \\
(0.034)\end{array}$ & - & $\begin{array}{l}-0.131 \\
(0.255)\end{array}$ & - \\
\hline $\begin{array}{l}\text { Political Constraint } \\
\text { Index }\end{array}$ & $\begin{array}{r}-0.744^{*} \\
(0.166)\end{array}$ & - & $\begin{array}{l}-0.638 \\
(3.180)\end{array}$ & - \\
\hline $\begin{array}{l}\text { Law and Order } \\
\text { Tradition Index }\end{array}$ & $\begin{array}{c}-0.512 * * * \\
(0.052)\end{array}$ & - & $\begin{array}{c}-3.832 * * * \\
(0.877)\end{array}$ & - \\
\hline GDP Growth Rate & $\begin{array}{c}0.078 * * \\
(0.030)\end{array}$ & - & $\begin{array}{l}-0.805 \\
(0.524)\end{array}$ & - \\
\hline $\begin{array}{l}\text { Dummy (During the } \\
\text { Financial Crisis, } \\
\text { 2007-2009) }\end{array}$ & $\begin{array}{c}1.288 * * * \\
(0.243)\end{array}$ & - & $\begin{array}{c}-9.816^{* *} \\
(4.378)\end{array}$ & - \\
\hline \multicolumn{5}{|l|}{ BRICS Country Dummies } \\
\hline Brazil & - & $\begin{array}{c}0.274 * * \\
(0.112)\end{array}$ & - & $\begin{array}{c}-14.24 * * * \\
(4.359)\end{array}$ \\
\hline China & - & $\begin{array}{c}0.552 * * * \\
(0.116)\end{array}$ & - & $\begin{array}{c}-12.86^{* *} \\
(5.395)\end{array}$ \\
\hline India & - & $\begin{array}{l}1.051 * * * \\
(0.108)\end{array}$ & - & $\begin{array}{c}-12.06 * * \\
(4.377)\end{array}$ \\
\hline Russia & - & $\begin{array}{c}1.053 * * * \\
(0.104) \\
\end{array}$ & - & $\begin{array}{c}-9.358 * * \\
(4.468) \\
\end{array}$ \\
\hline Sector Fixed Effect & Yes & & Yes & \\
\hline Year Fixed Effect & Yes & & Yes & \\
\hline \# of Observation & 13,810 & & 1,602 & \\
\hline
\end{tabular}

Note: $* * *, * *$, and $*$ represent significance at $1 \%, 5 \%$ and $10 \%$, respectively.

Our findings generated the following conclusions. Young and small enterprises do not have enough power to ignore threats from the authorities. Disciplinary agencies usually do not pay much attention to these firms to enforce comprehensive financial audits. Meanwhile, small firms are also not capable of adopting or developing solid procedures to business frauds such as bribery. Inevitably, small firms are more likely to become victims of predatory "rent seeking" extortions. In addition, infrastructural defects and rising risks increase motivation to seek protection-including bribing government officials - in order to achieve more convenience 
offered by the corrupt authority. A country's aggregate environment is also a significant factor. Naturally, firms bribe more frequently in corrupt and politically rigid countries.

There are also several policy implications generated from this study. First of all, the government must endeavor to control corruption, especially among the small business. A healthy environment for the growth of small firms is necessary, and crucial for cleaning up a developing country's economy. Second, national infrastructure needs to be improved; the efficiency of resource allocation needs to be enhanced, and the stability of the society needs to be guaranteed. Third, the government must also emphasize on financial auditing across all the firms, and strengthen the legal force. More political flexibility is also helpful in cracking down corruption.

\section{Concluding remarks}

Using a unique dataset from Enterprise Survey conducted by the World Bank from 2002 to 2012, we studied a highly interesting subject, why firms bribe. Focusing on such newly emerging economies as those in the BRICS countries, we selected a sample of firms with clear "yes" or "no" answer to the as whether they bribed. Both firm-level and country-level factors were studied. At the firm level, small employment size, less growth experience, and infrastructural defects all make a firm more likely to bribe. Poor infrastructure also cause bribing firms spend more in briberies. At the country level, a more corrupt environment, faster economic development, and lower willingness of people to accept the lawmakers' decisions can increase the probability that a firm bribes. During the 2007-2009 financial crisis, not only did BRICS firms become more likely to bribe, but they also tended to spend more in bribing.

\section{References}

Campos, J., Lien, D. and Pradhan, S. (1999) The impact of corruption on investment: predictability matters, World Development, 27(6), 1059-1067.

Clarke, G. and Xu, L. (2004) Privatization, competition, and corruption: how characteristics of bribe takers and payers affect bribes to utilities, Journal of Public Economics, 88(9), 2067-2097.

Chen, Y., Yaşar, M. and Rejesus, R. M. (2008) Factors influencing the incidence of bribery payouts by firms: A cross-country analysis, Journal of Business Ethics, 77(2), 231-244.

Cheung, Y. L., Rau, R. and Stouraitis, A. (2012) How much do firms pay as bribes and what benefits do they get? Evidence from corruption cases worldwide, National Bureau of Economic Research, working paper, No. w17981.

Henisz, W. (2002) The institutional environment for infrastructure investment, Industrial and Corporate Change, 11(2), 355-389.

Kaufmann, D. and Wei, S.J. (1999) Does "grease money" speed up the wheels of commerce?, National Bureau of Economic Research, working paper, No. w7093.

Keefer, P. and Knack, S. (1997) Why don't poor countries catch up? A cross-national test of an institutional explanation, Economic Inquiry, 35(3), 590-602.

Martin, K., Cullen, J., Johnson, J. and Parboteeah, K. (2007) Deciding to bribe: a cross-level analysis of firm and home country influences on bribery activity, Academy of Management Journal, 50(6), 1401-1422.

Méon, P. and Sekkat, K. (2005) Does corruption grease or sand the wheels of growth?, Public Choice, 122(1-2), 69-97.

Myrdal, G. (1968) Asian drama: an inquiry into the poverty of nations, Pantheon Books: New York. 
Powpaka, S. (2002) Factors affecting managers' decision to bribe: An empirical investigation, Journal of Business Ethics, 40(3), 227-246.

Sanyal, R. (2005) Determinants of bribery in international business: The cultural and economic factors, Journal of Business Ethics, 59(1-2), 139-145.

Svensson, J. (2003) Who must pay bribe and how much? Evidence from a cross-section of firms, Quarterly Journal of Economics, 118(1), 207-230.

Wu, X. (2009) Determinants of bribery in asian firms: evidence from the world business environment survey, Journal of Business Ethics, 87(1), 75-88. 